\title{
Possibilities the Rolling Reduction by REFERENCING DIRECTION WITH SUSPENSION CORRELATION
}

\author{
THIERHEIMER, W. W.; TANE, N.; THIERHEIMER, D. C. \& \\ ARDELEANU, D.
}

Abstract: In this paper, the important error induced by wheel suspending mechanism from rolling movement is reduced by means of solution proposed. This particular case we considered the elements that have big influence in dynamic behavior of the automotive, such as: steering geometry, the particular aspects regarding constructive solution. The problem of kinematical, dynamical and mathematical models is considered to characterize the dynamical behaviour of vehicles on curvilinear movement. The theoretical and experimental data comparison confirms with good accuracy the hypothesis made on the study of vehicle's stabilization system.

Key words: maniability, control, suspension, kinematics
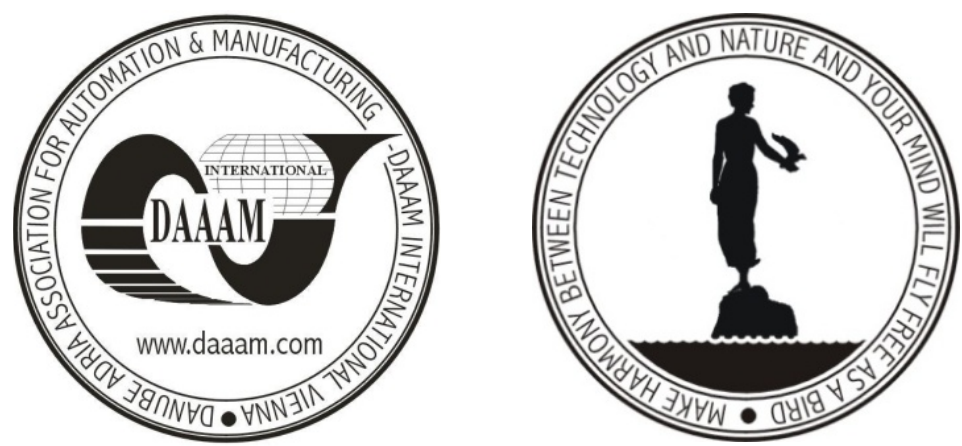

Authors' data: Assoc.Prof. Dr.-Eng.MSc. Thierheimer, W[alter] W[ilhelm]; Prof.Dr.-Eng. Tane, N[icolae]; Drd.-Eng. MSc. Thierheimer, D[iana] C[amelia]; Assist.Prof. Dr.-Eng. Ardeleanu, D[ragos], Transilvania University of Brasov, Plotehnicii str., nr. 3, ap. 6, 500019, Brasov, RO, thierheimer@unitbv.ro, nictan54r@unitbv.ro, boldor@vega.unitbv.ro, ardeleanu_d@unitbv.ro

This Publication has to be referred as: Thierheimer, W[alter] W[ilhelm]; Tane, N[icolae]; Thierheimer, D[iana] C[amelia] \& Ardeleanu, D[ragos] (2009). Possibilities the Rolling Reduction by Referencing Direction with Suspension Correlation, Chapter 46 in DAAAM International Scientific Book 2009, pp. 453-470, B. Katalinic (Ed.), Published by DAAAM International, ISBN 978-3-901509-69-8, ISSN 1726-9687, Vienna, Austria DOI: 10.2507/daaam.scibook.2009.46 